\title{
Antioxidant Activities of Ethanoilc Extracts of Spilanthes uliginosa, Ocimum basilicum, Hyptis spicigera and Cymbopogon citratus against Swiss Mice Exposed to Plasmodium berghei Anka 65
}

\author{
K. N. Agbafor' ${ }^{*}$, A. J. Uraku1, A. N. C. Okaka², U. A. Ibiam¹, P. M. Ajah'1, O. U. Obasi ${ }^{1}$ \\ ${ }^{1}$ Department of Biochemistry, Ebonyi State University, Abakaliki, Nigeria \\ ${ }^{2}$ Department of Biochemistry, Nnamdi Azikiwe University, Awka, Nigeria \\ Email: ${ }^{*}$ kagbafor@yahoo.co.uk, nagbafor@gmail.com
}

Received 12 December 2014; revised 26 December 2014; accepted 3 January 2015

Copyright (C) 2015 by authors and Scientific Research Publishing Inc.

This work is licensed under the Creative Commons Attribution International License (CC BY). http://creativecommons.org/licenses/by/4.0/

\section{(c) (i) Open Access}

\section{Abstract}

Malaria infection is associated with increased generation of free radicals. This study investigated the antioxidant activity of ethanolic leaf extracts of Spilanthes uliginosa, Ocimum basilicum, Hyptis spicigera and Cymbopogon citratus. Seventy two (72) swiss mice of both sexes were used. All the mice were treated intraperitoneally with $0.2 \mathrm{ml}$ parasitized blood suspension and parasitemia assessed by thin blood films stained with Geimsa stain after seventy two hours. The mice were divided into six groups namely; A, B, C, D, E, and F of twelve mice each. Groups B, C, D and E were subdivided into three (3): $B_{1}, B_{2}, B_{3}, C_{1}, C_{2}, C_{3}, D_{1}, D_{2}, D_{3}, E_{1}, E_{2}$ and $E_{3}$, four in each subgroup. The subgroups were treated with the extracts of Spilanthes uliginosa $(\mathrm{Sw})$, Ocimum basilicum, Hyptis spiligera and Cymbopogon citratus each for five (5) consecutive days with 200,400 and $800 \mathrm{mg} / \mathrm{kg}$ body weight respectively via oral intubation. Two control groups, $A$ and $F$ were used. The negative control (A) was treated daily with $5 \mathrm{ml} / \mathrm{kg}$ normal saline while positive control group (F) was treated with $5 \mathrm{mg} / \mathrm{kg}$ body weight of chloroquine. The results indicated a general significant $(\mathrm{P}<$ 0.05) decrease in the lipid peroxidation concentrations of the parasitized treated mice when compared to parasitized untreated mice on the last day. A general significant dose dependent increase $(P<0.05)$ was observed in superoxide dismutase (SOD), catalase and glutathione perioxidase activities as well as reduced glutathione concentrations in the treated mice except at a dosage of $200 \mathrm{mg} / \mathrm{kg}$ body weight for all the plants. The effects of the extracts were significantly higher $(P<0.05)$ than that of chloroquine. These results suggest that the ethanolic extracts of

\footnotetext{
Corresponding author.
}

How to cite this paper: Agbafor, K.N., et al. (2015) Antioxidant Activities of Ethanoilc Extracts of Spilanthes uliginosa, Ocimum basilicum, Hyptis spicigera and Cymbopogon citratus against Swiss Mice Exposed to Plasmodium berghei Anka 65. American Journal of Plant Sciences, 6, 64-72. http://dx.doi.org/10.4236/ajps.2015.61008 
these plants may contribute to the protection of malaria infected mice against oxidative damage by improving antioxidant status in a dose dependent manner.

\title{
Keywords
}

\author{
Oxidative Stress, Plasmodium berghei, Medicinal Plants, Malaria, Swiss Mice
}

\section{Introduction}

The use of plants for treating diseases is as old as the human species. All over the globe the use of medicinal plants has significantly supported primary health care [1]. Spilanthes uliginosa (Sw), commonly known as eyeball plant, is an annual herb or short-lived perennial which grow up to $30-60 \mathrm{~cm}$ high in swampy, damp sites and road sites. The leaves and other parts are claimed to control the symptoms of various types of infections and stimulation of immunity. Ocimum basilicum L. (commonly known as scent leave) is native to Africa, Asia and Pacific Island and is of the family Lamiaceae. The plants in this family are mostly annual or perennial herbs. The plant has been used in the treatment of headaches, coughs, diarrhea, constipation, warts, worms, kidney malfunctions and other disorders. Hyptis spicigera (Lamiaceae) is an aromatic annual plant with opposite and lanceolate leaves. The decoction of Hyptis spicigera is used as bath water or tea, as eupneic, or expectorant to treat bronchial infections and other diseases. Cymbopogon citratus, commonly known as lemongrass, is a tropical perennial herb belonging to the family Poaceae (true grasses). It has been mentioned to be effective in the treatment of fever, infections, digestive disorders, menstrual disorder, headaches, stomach aches, joint and rheumatic pains [2].

Malaria is an enormous public health problem worldwide and kills one - two million people annually, mostly children under the age of five and pregnant women residing in Africa [3]. Thus, malaria is the most lethal parasitic disease in the world, annually affecting approximately 500 million people mostly in African Sub-sahara countries [4].

Malaria infection in human and animals is caused by the parasite Plasmodium [5]. Several species of Plasmodium have the ability to cause malaria in animals, including rodents. The most common Plasmodium species used to infect laboratory mice is Plasmodium berghei. Plasmodium berghei is a unicellular parasite that infects mammals other than humans.

A prime event in malaria infection is increased production of highly reactive oxygen species (ROS) by host cell system, malaria parasite itself and its activities [6]. This involvement may be related to the pathogenic mechanisms triggered by the parasite [7], as well as free radical production [8] and antioxidant defenses [9] in host cell to abate the infection.

The role of oxidative stress during malaria infection is still unclear. Although, some researchers suggest a protective role while others claim a relation to the physiopathology of the disease [9]. However, studies suggest that the generation of reactive oxygen species and reactive nitrogen species (ROS and RNS) associated with oxidative stress, play a crucial role in the development of systemic complications caused by malaria [10]. Furthermore, malaria infection induces the generation of hydroxyl radical $(\mathrm{OH})$ in the liver, which most probably is the main reason for the induction of oxidative stress and apoptosis [11].

A potential source of free radical production in this disease is the host's hemoglobin molecule, since the parasite uses this molecule as a source of amino acids for its own nutrition during the erythrocytic stage of the disease [12].

This research was designed to assess the ability of the plant extracts lower the oxidative stress caused by malaria infection.

\section{Materials and Methods}

\subsection{Collection of Plant Material}

Fresh leaves of Spilanthes uliginosa, Ocimum basilicum, Hyptis spicigera and Cymbopogon citratus were collected from Ogboji-Agoutu Ezzagu in Inyaba Development Centre of Ebonyi State, Nigeria. They were identified by Prof. S. C. Onyekwelu of Applied Biology Department, Ebonyi State University, Abakaliki. 


\subsection{Extraction of Plant Materials}

The leaves were cleaned, air-dried and pounded into fine powder using an electric blender. The powder was stored in an airtight container and kept in a cool, dry place.

Exactly $150 \mathrm{~g}$ of powder samples of each of Spilanthes uliginosa, Ocimum basilicum, Hyptis spicigera and Cymbopogon citratus were separately soaked in $500 \mathrm{ml}$ of ethanol for 24 hours. They were filtered into a graduated beaker and exposed to mild heat at $40^{\circ} \mathrm{C}$ in water bath until semi solid extracts were obtained.

\subsection{Experimental Animals}

Ethical approval was given by Ebonyi State University Research and Ethics Committee. Seventy two (72) Swiss albino mice aged 2 months and weighing 17 - $34 \mathrm{~g}$ of both sexes were obtained from animal house of Nnamdi Azikiwe University Awka, Anambra State, Nigeria and transferred to Animal house of Department of Biochemistry, Ebonyi State University, Abakalki. The animals were housed in metal cages under controlled conditions and acclimatized for 7 days under standard environment conditions and fed ad-libitum on their normal diets.

\subsection{Rodent Parasite (Plasmodium berghei ANKA 65)}

The rodent parasite was sourced from National Institute for Medical Research (NIMR), Lagos, Nigeria and maintained alive in mice by continuous intraperitoneal passage in mice after every 5 days. The reinfected mice were moved to the Animal House of Department of Biochemistry, Ebonyi State University, Abakaliki, where the study was carried out. Prior to the start of the study, one of the infected mice was kept and observed to reproduce signs of disease similar to human malarial infection.

\subsection{Inoculation of Animals}

The mice were infected with parasites consisting of $1 \times 10^{7}$ of $P$. berghei parasitized erythrocytes per ml. This was carried out by determining both the percentage parasitaemia and erythrocytes count of the donor mouse and diluting the blood with phosphate buffer saline $\mathrm{pH} 7.4$ in proportions indicated by both determinations. Each mouse was inoculated intraperitoneally with $0.2 \mathrm{ml}$ of infected blood containing $1 \times 10^{7} \mathrm{P}$. berghei parasitized red blood cells. Parasitaemia was assessed by thin blood film made by collecting blood from the cut tip of the tail and this was stained with Geimisia stain [4].

\subsection{Experimental Design}

Seventy two (72) swizz mice of both sexes were used. All the mice were injected intraperitoneally with standard inoculums of $1 \times 10^{7} \mathrm{P}$. berghei ANKA 65 infected erythrocytes on the first day.

Seventy two hours later, the mice were divided into six groups namely; A, B, C, D, E, and F of twelve mice each. Groups B, C, D and E were subdivided into three (3): $B_{1}, B_{2}, B_{3}, C_{1}, C_{2}, C_{3}, D_{1}, D_{2}, D_{3}, E_{1}, E_{2}$ and $E_{3}$, each containing four mice. The subgroups were treated with the extracts of Spilanthes uliginosa $(\mathrm{Sw})$, Ocimum basilicum, Hyptis spiligera and Cymbopogon citratus each for five (5) consecutive days with 200, 400 and 800 $\mathrm{mg} / \mathrm{kg}$ body weight respectively via oral intubation. Two control groups, A and F were used. The negative control (A) was treated daily with $5 \mathrm{ml} / \mathrm{kg}$ normal saline, while positive control group (F) was treated with $5 \mathrm{mg} / \mathrm{kg}$ body weight of chloroquine, an antimalaria drug. On the sixth day mice were starved overnight and sacrificed.

\subsection{Preparation of Serum}

Fasting blood was collected from each mice into a sterile, plain tube, and then it was centrifuged at $1200 \times \mathrm{g}$ for $5 \mathrm{~min}$ at room temperature to obtain the serum.

\subsection{Determination of SOD Activity}

Superoxide dismutase was assayed as described by Misra and Fridovich [13] with little modification. $0.5 \mathrm{ml}$ of serum and $1.5 \mathrm{ml}$ of phosphate buffer $\mathrm{pH} 7.8$ were added into a test tube and mixed thoroughly. Then, the mixture was centrifuged for 5 minutes. $0.2 \mathrm{ml}$ of the supernatant was transferred into another test tube. $2.5 \mathrm{ml}$ of phosphate buffer and $0.5 \mathrm{ml}$ of adrenaline $(0.011 \mathrm{ml}$ epinepherine) were added to the test tube containing the 
supernatant. The absorbance of the test at $480 \mathrm{~nm}$ wavelength was read at interval of 30 seconds for 3 minutes against the blank.

\subsection{Determination of Catalase (CAT) Activity}

The activity of catalase was assayed using a modified method of Idorenyin et al., [14]. The percentage inhibition was evaluated following decrease in absorbance at $620 \mathrm{~nm} .0 .5 \mathrm{ml}$ of serum and $4.5 \mathrm{ml}$ of phosphate buffer of $\mathrm{pH} 7.0$ were added into a test tube and mixed thoroughly for 5 minutes and centrifuged for 5 minutes. $4 \mathrm{ml}$ of $\mathrm{H}_{2} \mathrm{O}_{2}$ and $5 \mathrm{ml}$ of phosphate buffer were added into a separate test tube. To another test tube, $2 \mathrm{ml}$ of dichromate acetic acid reagent was added. $1 \mathrm{ml}$ of the sample in phosphate buffer was added to the test tube containing the $\mathrm{H}_{2} \mathrm{O}_{2}$ and phosphate buffer. At 1 minute interval, $2 \mathrm{ml}$ of dichromate acetic acid was added. This repeated for 5 minutes. The absorbance of the test at $620 \mathrm{~nm}$ wavelength was read against the blank.

Percentage inhibition was calculated using the equation:

$$
\% \text { catalase inhibition }=[(\text { normal activity }- \text { inhibited activity }) /(\text { normal activity })] \times 100 \%
$$

\subsection{Determination of Glutathione Peroxidase (GPX)}

$0.1 \mathrm{ml}$ of serum and $1 \mathrm{ml}$ of O-dianisidine solution were added to a test tube labeled test. $2 \mathrm{ml}$ of phosphate buffer of PH 6.5 was added equally to the same test tube and mixed thoroughly. The reaction was initiated by adding $0.1 \mathrm{ml}$ of $0.2 \times 10^{-2} \mathrm{M}$ of $\mathrm{H}_{2} \mathrm{O}_{2}$ to the same test tube. To test tube labeled blank, all reagents added to the test were also added except serum. Then, the absorbance of the test at $460 \mathrm{~nm}$ wavelength was read at every 30 seconds interval up to 5 minutes against the blank [3].

\subsection{Determination of Reduced Glutathione (GSH)}

Reduced glutathione was determined using the modified method of Moron et al. [15]. $0.1 \mathrm{ml}$ of sample and 0.02 $\mathrm{ml}$ of $2 \%$ sodium sulphate solution were added to a test tube, mixed and allowed to stand for 2 minutes. $0.02 \mathrm{ml}$ of $2 \%$ litium sulphate was also added and mixed thoroughly. $0.2 \mathrm{ml}$ of $2 \%$ sodium carbonate was equally added and mixed gently. Then, $0.2 \mathrm{ml}$ of phosphate ethenoic acid reagent was added again and mixed thoroughly. 1.76 $\mathrm{ml}$ of $2 \%$ sodium sulphate solution was added after 4 minutes mixed and centrifuged for 5 minutes. The absorbance of the test was read at $610 \mathrm{~nm}$ against the blank.

\subsection{Determination of Lipid Peroxidation}

Lipid peroxidation in the liver was estimated colorimetrically by thiobarbituric acid reactive substances (TBARS) using the modification method of Niehius and Samuelsson [16]. $0.5 \mathrm{ml}$ of serum and $0.5 \mathrm{ml}$ of normal saline were added into a test tube and mixed. $1 \mathrm{ml}$ of $10 \%$ TCA and $1 \mathrm{ml}$ of 5\% TBA in $0.3 \mathrm{NaOH}$ were added to the same test tube. The mixture was boiled in a water bath for 40 minutes and cool in cold water. Then, $0.1 \mathrm{ml}$ of $20 \%$ SDS was also added to the cold mixture and allowed to stand for 5minutes. The SDS mixed solution was centrifuged for 5 minutes and the absorbance of the supernatant was read at $532 \mathrm{~nm}$ against the blank. Percentage inhibition was calculated using the equation:

$$
\% \text { lipids Inhibition }=\{A o-A 1\} / A o \times 100
$$

where; $A o$ is the absorbance of the control and $A 1$ is the absorbance of the sample extract.

\subsection{Statistics}

The repeat measure analysis of variance (ANOVA) was used to compare similar mean values, and the group means with their standard deviation were compared by Duncan's multiple range test (DMRT). The level of statistical significance was established at 5\% probability level.

\section{Results of Antioxidant Activities in Mice Treated with Ethanol Leaf Extracts.}

The results of Superoxide dismutase (SOD), Catalase (CAT), Glutathione peroxidase (GPX) activities, Glutathione (GSH) and malondiadehyde (MDA) levels of the treated and untreated mice are shown in Figures 1-5 respectively. 


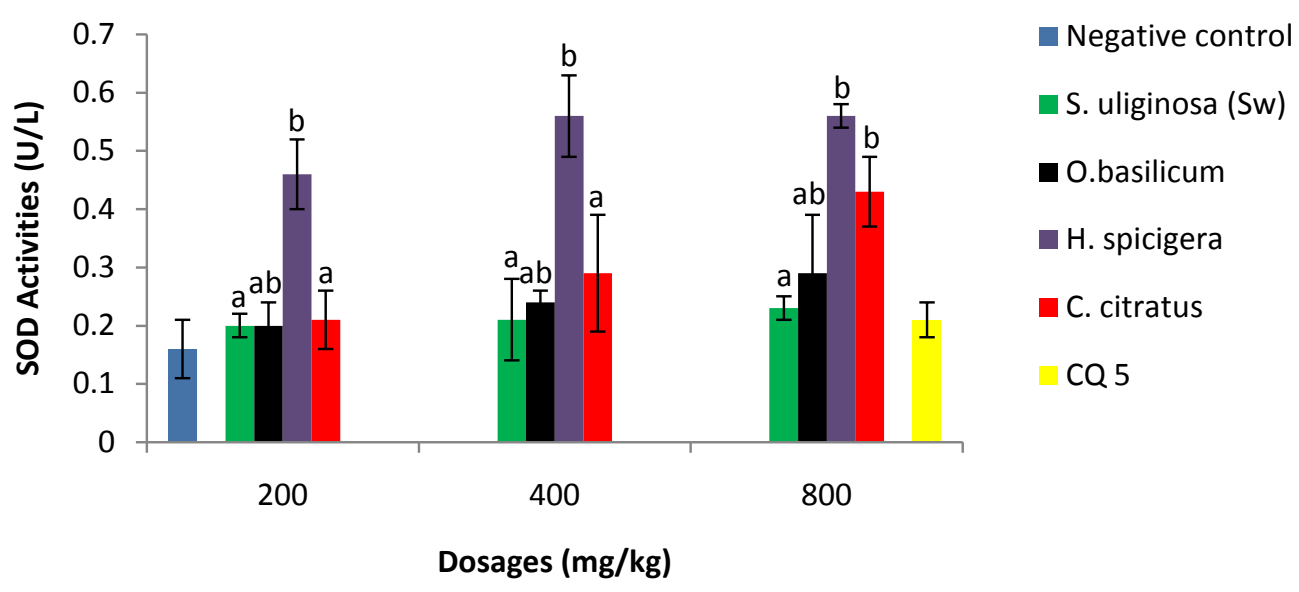

Figure 1. The results of superoxide dismutase activities $(\mu / \mathrm{l})$ in treated and untreated mice. Bars bearing the same letters (dosage by dosage for each plant) are not significantly different from each other $(\mathrm{P}>0.05)$.

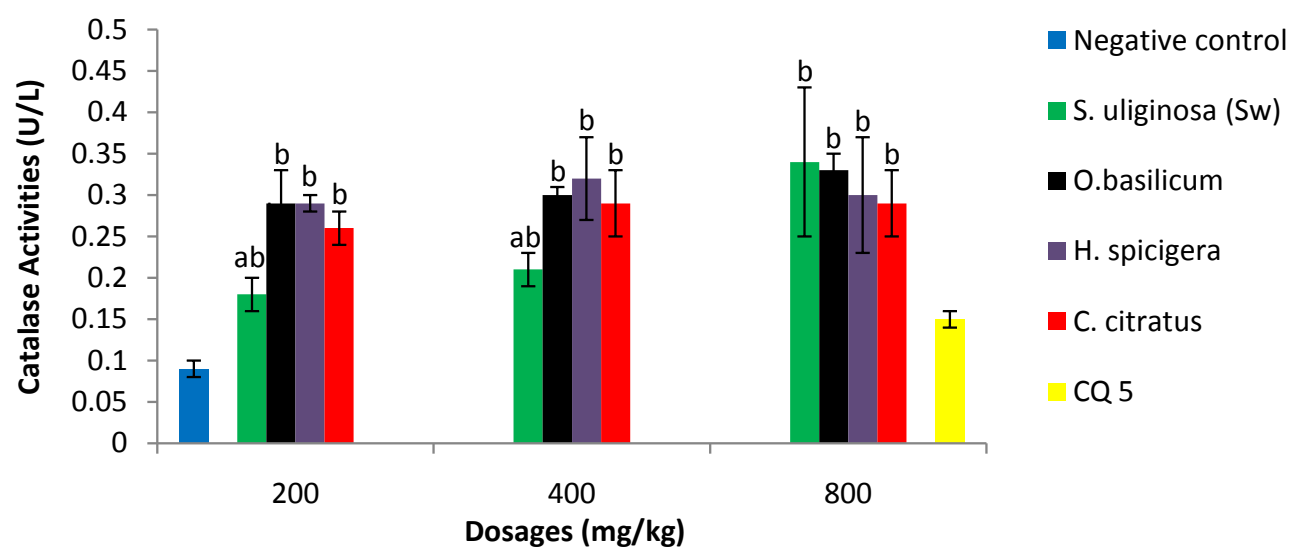

Figure 2. The results of Catalase activities $(\mu / \mathrm{l})$ in treated and untreated mice. Bars bearing the same letters (dosage by dosage for each plant) are not significantly different from each other $(\mathrm{P}>0.05)$.

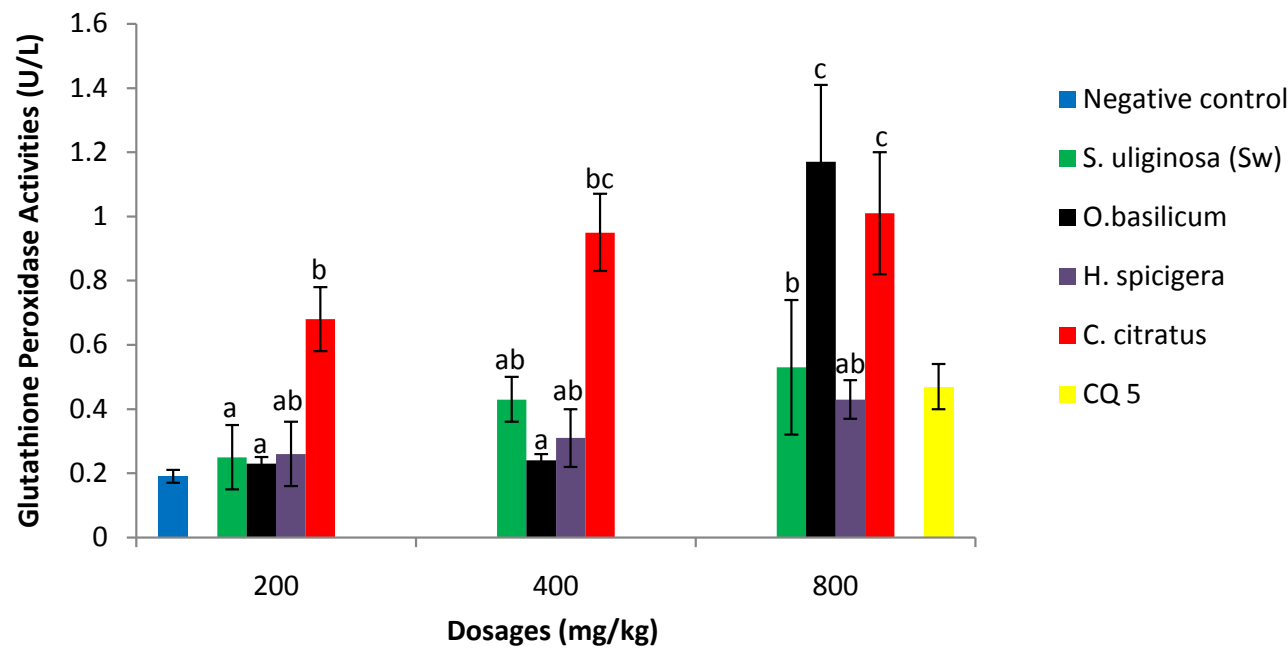

Figure 3. The results of Glutathione peroxidase activities $(\mu / \mathrm{l})$ in treated and untreated mice. Bars bearing the same letters (dosage by dosage for each plant) are not significantly different from each other $(\mathrm{P}>0.05)$. 


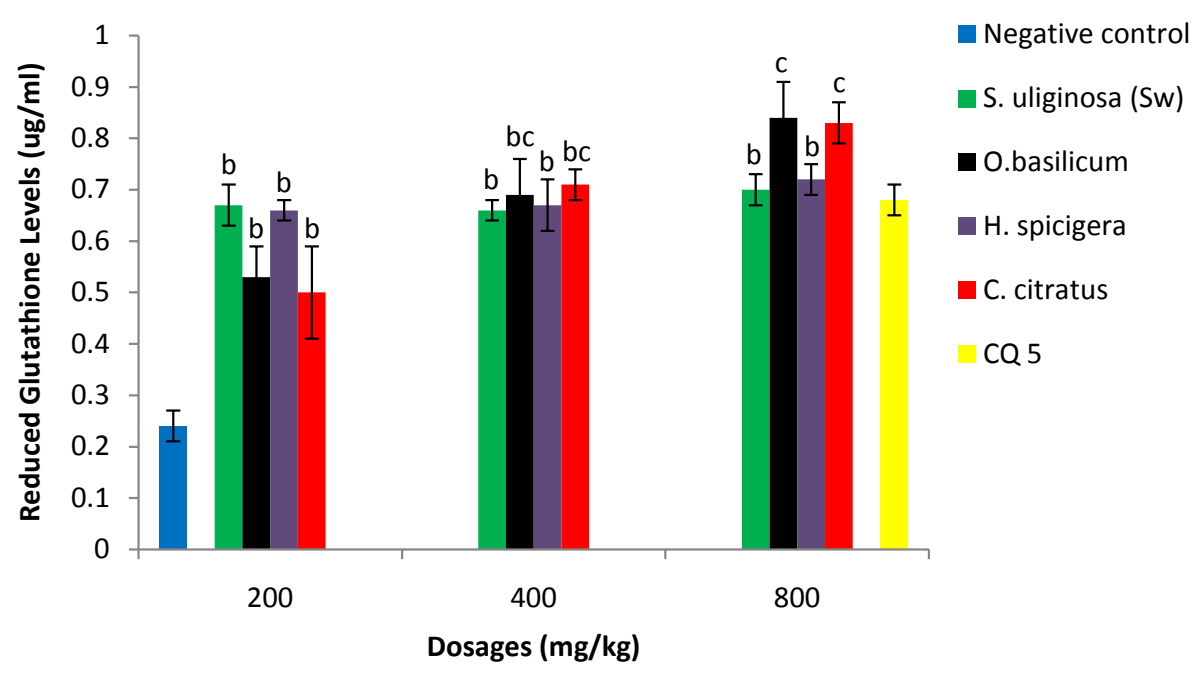

Figure 4. The results of reduced glutathione levels $(\mu \mathrm{g} / \mathrm{ml})$ in treated and untreated mice. Bars bearing the same letters (dosage by dosage for each plant) are not significantly different from each other $(\mathrm{P}>0.05)$.

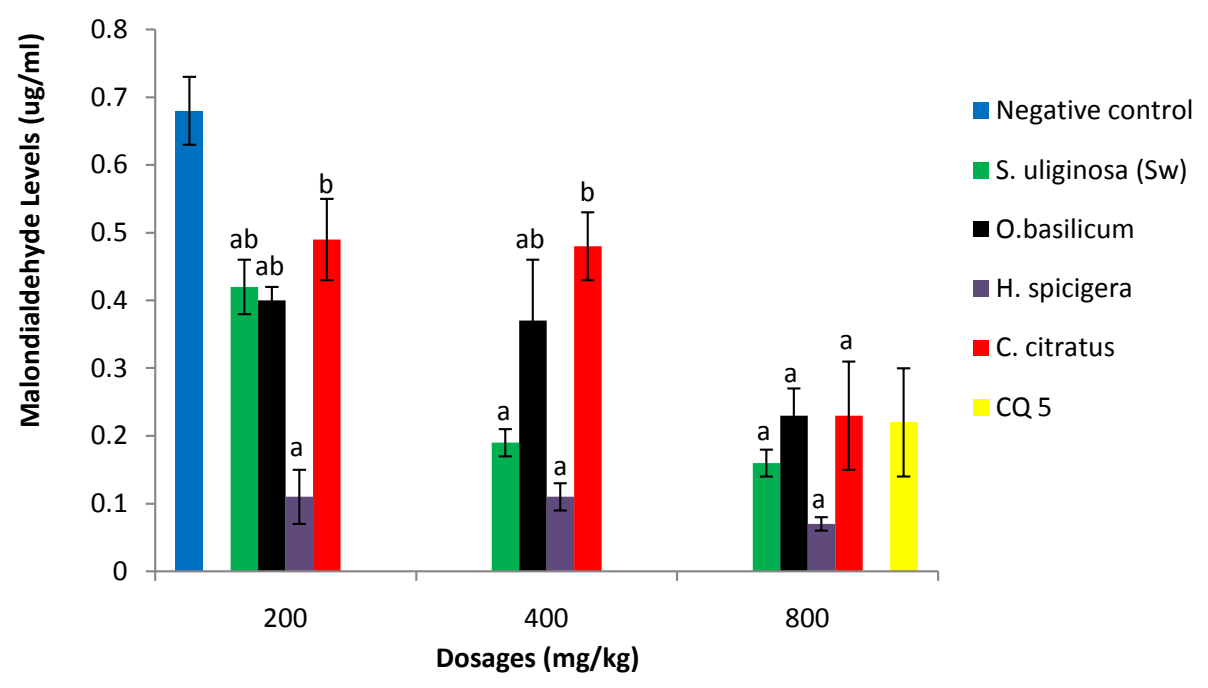

Figure 5. The results of malondiadehyde (MDA) levels $(\mu \mathrm{g} / \mathrm{ml})$ in treated and untreated mice. Bars bearing the same letters (dosage by dosage for each plant) are not significantly different from each other $(\mathrm{P}>0.05)$.

The results of superoxide dismutase activities are shown in Figure 1. The results showed that there was significant elevation $(\mathrm{P}<0.05)$ in the activity of SOD for the extracts of $C$. citratus and $H$. spicigera at all varying doses and that of $C$. citratus at only $800 \mathrm{mg} / \mathrm{kg}$ when compared to negative control. There were significant difference $(\mathrm{P}<0.05)$ between the effect of the standard drug and negative control in the only extract of $O$. basilicum. There was no significant difference $(\mathrm{P}>0.05)$ between the effects of the standard drug and the extracts of S. uliginosa (Sw) and O. basilicum at all varying doses used and that of C. citratus at 200 and $400 \mathrm{mg} / \mathrm{kg}$. The extracts S. uliginosa (Sw), O. basilicum and H. spicigera at all given doses and that of C. citratus at 200 and 400 $\mathrm{mg} / \mathrm{kg}$ had no significant differences $(\mathrm{P}>0.05)$ when compared to other doses.

The results of Catalase activities are shown in Figure 2. There was significant increase $(P<0.05)$ in the activity of Catalase for all the extracts at all varying doses when compared to negative control. There was no significant difference $(\mathrm{P}>0.05)$ between the effects of the standard drug and the extract of S. uliginosa $(S w)$ at 200 and $400 \mathrm{mg} / \mathrm{kg}$. However, there were marked significant difference $(\mathrm{P}<0.05)$ between the effects of the standard drug and the extracts of Ocimum basilicum, $H$. spicigera and C. citratus at varying doses used. The extracts S. uliginosa (Sw) at 200 and $400 \mathrm{mg} / \mathrm{kg}$ and that of $H$. spicigera at 400 and $800 \mathrm{mg} / \mathrm{kg}$ as well as O. basilicum 
and C. citratus at all given doses had no significant differences $(\mathrm{P}>0.05)$ when compared to other doses.

The results of Glutathione peroxidase activities are shown in Figure 3. According to the results, $s$ there was significant rise $(\mathrm{P}<0.05)$ in the activity of Glutathione peroxidase for all the extracts at all varying doses except S. uliginosa (Sw) at only $200 \mathrm{mg} / \mathrm{kg}$ and $O$. basilicum at 200 and $400 \mathrm{mg} / \mathrm{kg}$ when compared to negative control. There was no significant difference $(\mathrm{P}>0.05)$ between the effects of the standard drug and the extract of $S$. uliginosa (Sw) at only $400 \mathrm{mg} / \mathrm{kg}$ and C. citratus at $200 \mathrm{mg} / \mathrm{kg}$ and that of $H$. spicigera at varying doses used. However, there were marked significant difference $(\mathrm{P}<0.05)$ between the effects of the standard drug and the extract of $O$. basilicum at varying doses used. The extract of $O$. basilicum at 200 and $400 \mathrm{mg} / \mathrm{kg}$ and $\mathrm{H}$. spicige$r a$ at all doses had no significant differences $(\mathrm{P}>0.05)$ when compared to other doses while the extracts of $S$. uliginosa $(\mathrm{Sw})$ and $C$. citratus at varying doses used caused a significant differences $(\mathrm{P}<0.05)$ when compared to other doses.

The results of reduced glutathione levels are shown in Figure 4. The results revealed a significant elevation $(\mathrm{P}<0.05)$ in the level of reduced glutathione for all the extracts at all varying doses when compared to negative control. There was no significant difference $(\mathrm{P}>0.05)$ between the effects of the standard drug and the extract of S. uliginosa $(S w)$ and $H$. spicigera at all given doses and that of $O$. basilicum and C. citratus at $400 \mathrm{mg} / \mathrm{kg}$. However, there were marked significant difference $(\mathrm{P}<0.05)$ between the effects of the standard drug and the extract of O. basilicum and C. citratus at 200 and $800 \mathrm{mg} / \mathrm{kg}$. The extract of S. uliginosa (Sw) and H. spicigera at all doses used had no significant differences $(\mathrm{P}>0.05)$ when compared to other doses while the extracts of $O$. basilicum and C. citratus at varying doses used caused a significant differences $(\mathrm{P}<0.05)$ when compared to other doses.

The results of malondiadehyde (MDA) levels are shown in Figure 5. The results showed that there were significant reduction $(\mathrm{P}<0.05)$ in the level of MDA for all the extracts at all varying doses when compared to negative control. There was no significant difference $(\mathrm{P}>0.05)$ between the effects of the standard drug and the extract of S. uliginosa $(S w)$ at 400 and $800 \mathrm{mg} / \mathrm{kg}$ and that of $O$. basilicum and C. citratus at only $800 \mathrm{mg} / \mathrm{kg}$. However, there were marked significant difference $(\mathrm{P}<0.05)$ between the effects of the standard drug and the extract of H. spicigera at all doses. The extract of S. uliginosa (Sw) at 400 and $800 \mathrm{mg} / \mathrm{kg}$ as well as O. basilicum and C. citratus at 200 and $400 \mathrm{mg} / \mathrm{kg}$ and that of $H$. spicigera at all doses used had no significant differences $(\mathrm{P}>0.05)$ when compared to other doses.

\section{Discussion}

In tropics and subtropics regions of the world, the endemic nature of malaria as well as the morbidity and mortality associated with the infection particularly among children under the ages of five and pregnant women is of great concern [17] [18]. Malaria may be considered as a complex disease rather than a single illness because it is associated with other ailments.

The results revealed an increase in lipid perioxidation levels and decrease in the activities of superoxide dismutase (SOD), catalase (CAT) and glutathione perioxidase (GPx) and the concentrations of reduced glutathione (GSH) in parasitized untreated mice when compared to treated mice, which suggest an oxidative environment and stress in parasitized mice. This could be because of dynamic changes in multiple body systems which result in increased basal oxygen consumption [19]. Also, this might have occurred as a result of toxic effect of upsurge reactive oxygen speies produced by immune system as well as synchronized release of $\mathrm{O}^{2-}$ during haemoglbin degradation by malaria parasite [12].

There were general increase in the activities of superoxide dismutase (SOD), catalase (CAT) and glutathione perioxidase (GPx) and the concentrations of reduced glutathione (GSH) in the parasitized treated animals when compared to parasitized un-treated animals. The results are in agreement with the report of Gulrana et al. [20] which states that all antioxidant defenses are interconnected hence disruption of one would disrupt the whole microenvironment and vice versa. Decrease in the activities and concentrations of these antioxidants in parasitized un-treated animals were an indication of a surplus amount of free radical generation which promotes oxidative stress induced by malaria parasites in Plasmodium berghei and the host cell. Similarly, decreased SOD, CAT and GPx activities are linked up to exhaustion of the enzymes as a result of oxidative stress caused by Plasmodium berghei but restoration of SOD, CAT and GPx activities by the ethanol extracts indicated that the extracts scavenged superoxide radicals. Superoxide and nitric oxide radicals have been found to cause inactivation and nitration of the human superoxide dismutase enzyme [21]. Thus, the reversal effects were their protective actions via a decreased production of Plasmodium berghei derived free radicals or through the antioxidant 
activity of the protective agents themselves.

Reduction in liver GSH concentrations of parasitized untreated mice and corresponding increase in lipid peroxidation in Plasmodium berghei treated mice as observed in this study indicated antioxidant depletion resulting in damage to the hepatic cells by free radicals generated [15]. Increase in hepatic GSH concentration in ethanol extracts of treated group could either be due to an effect on the de novo synthesis of GSH, its regeneration or both. Reduction in lipid peroxide concentration showed that lipid peroxidation in Plasmodium bergheiinduced liver damage was prevented due to increases in the enzymatic antioxidant activity and non-enzymatic antioxidant concentration, resulting from treatment with ethanol extracts.

These observations are indicative of potentials of the extract in the prevention of oxidative stress induced by malaria parasite. Secondary plant metabolites like flavonoids, phenolic compounds, saponins, alkaloids, glycosides and tannins as well as vitamins such as vitamin A, E and C. etc. have earlier been shown to be present in these extracts. Thus, the antioxidant potentials exhibited by the Spilanthes uliginosa (Sw), Ocimum basilicum, Hyptis spicigera and Cymbopogon citratus extracts could be due to the synergistic effect of these agents. Also, it may be hypothesized that the reduced effects of free radicals observed in mice that received the extracts and 5 $\mathrm{mg} / \mathrm{kg}$ of chloroquine may be as a result of the quenching effects of the hydrogen rich organic acid and bioactive ingredients of the plant extracts on free radicals generated within the parasitized red cell, therefore stabilizing the cell membrane from the harmful manifestation of the free radicals generated from parasite degradation of host hemoglobin. Murray et al., [22] reported that cellular damage through oxidation of proteins, DNA and lipids may result if free radicals accumulate in the cell.

\section{References}

[1] Maciel, M.A.M., Pinto, A.C., Veiga Jr., V.F., Grynberg, N.F. and Echevarria, A. (2002) Medicinal Plants: The Need for Multidisciplinary Scientific Studies. Quim Nova, 25, 429-438. http://dx.doi.org/10.1590/S0100-40422002000300016

[2] Agbafor, K.N. and Akubugwo, E.I. (2007) Hypocholesterolemic Effect of Ethanol Extract of Fresh Leaves of Cymbopogon citratus. African Journal of Biotechnology, 6, 596-598.

[3] Oyedemi, S.O., Bradley, G. and Afolayan, A.J. (2010) In-Vitro and -Vivo Antioxidant Activities of Aqueous Extract of Strychnos henningsii Gilg. African Journal of Pharmacy and Pharmacology, 4, 70-78.

[4] WHO (2011) World Malaria Report. World Health Organization Press, Geneva.

[5] Tripathi, K.D. (2013) Essentials of Medical Pharmacology. 7th Edition, Jaypee Brothers Medical Publishers (P) Ltd., New Delhi, 816-835.

[6] Sandro, P., Danilo, R.M., Bruno, A.Q.G., Michelli, E.S.F., Ana, C.M.G., Paula, S.O.C.L., Thyago, C.V., Maria, F.D. and Michael, D.G. (2012) Oxidative Stress in Malaria. International Journal of Molecular Sciences, 13, 16346-16372. http://dx.doi.org/10.3390/ijms131216346

[7] Potter, S.M., Mitchell, A.J., Cowden, W.B., Sanni, A., Dinaner, M., Hann, J.B. and Hunt, N.H. (2005) Phagocyte-DeRived Reactive Oxygen Species Do Not Influence the Progreeion of Murine Blood-Stage Malaria Infection. Infection Immunology, 73, 4941-4947. http://dx.doi.org/10.1128/IAI.73.8.4941-4947.2005

[8] Keller, C.C., Kremesner, P.G., Hittner, J.B., misukonis, M.A., Weinberg, J.B. and Perkins, D.J. (2004) Elevated Nitric Oxide Production in Children with Malarial Anemia: Hemozoin-Induced Nitric Oxide Synthase Type 2 Transcripts and Nitric Oxide in Blood Mononuclear Cells. Infection Immunology, 72, 4868-4873. http://dx.doi.org/10.1128/IAI.72.8.4868-4873.2004

[9] Sohail, M., Kaul, A., Raziuddin, M. and Adak, T. (2007) Decreased Glutathione-S-Transferase Activity Diagnostic and Protective Role in Vivax Malaria. Clinical Biochemistry, 40, 377-382. http://dx.doi.org/10.1016/j.clinbiochem.2007.01.005

[10] Guha, M., Kumar, S., Choubey, V., Maity, P. and Bandyopadhya, U. (2006) Apoptosis in Liver during Malaria: Role of Oxidative Stress and Implication of Mitochondrial Pathway. FASEB Journal, 20, 439-449. http://dx.doi.org/10.1096/fj.05-5338fje

[11] Doekrell, H.M. and Playfair, J.H. (1984) Killing of Plasmodium yoelii by Enzyme-Induced Products of the Oxidative Burst. Infection and Immunity, 43, 451-456.

[12] Erel, O., Kocyigit, A., Avci, S., Aktepe, N. and Bulut, V. (1997) Oxidative Stress and Antioxidative Status of Plasma and Erythrocytes in Patients with Vivax Malaria. Clinical Biochemistry, 30, 631-639. http://dx.doi.org/10.1016/S0009-9120(97)00119-7

[13] Yakubu, M.T. and Omoniwa, B.P. (2012) Effects of Aqueous Stem Extract of Massularia Acuminata on Some Liver 
Function Indices of Male Rats. Iranian Journal of Toxicology, 6, 716-722.

[14] Umoh, I., Oyebadejo, S., Bassey, E. and Nnah, U. (2013) Chronic Consumption of Combined Extracts of Abelmoschus esculentus and Piper guineense Induced Hepatoxicity in Wistar Rats: Histopathological Study. International Journal of Pharmaceutical and Biomedical Science, 4, 73-77.

[15] Moron, M.S., Depierre, J.W. and Mannervik, B. (1979) Levels of Glutathione, Glutathione Reductase and Glutathione S-Transferase Activities in Rat Lung and Liver. Biochimica et Biophysica Acta, 582, 67-78. http://dx.doi.org/10.1016/0304-4165(79)90289-7

[16] Niehius, W.G. and Samuelson, B. (1968) Formation of Malonaldehyde from Phospholipid Arachidonate during Microsomal Lipid Peroxidation. European Journal of Biochemistry, 6, 126-130. http://dx.doi.org/10.1111/j.1432-1033.1968.tb00428.x

[17] Akanbi, O.M., Odaibo, A.B. and Ademowo, O.G. (2010) Effects of Antimalarial Drugs and Malaria Infection on Oxidative Stress in Pregnant Women. African Journal of Reproductive Health, 14, 209-212.

[18] George, B.O., Osioma, E., Okpoghono, J. and Aina, O.O. (2011) Changes in Liver and Serum Transaminases and Alkaline Phosphatase Enzyme Activities in Plasmodium berghei Infected Mice Treated with Aqueous Extract of Aframomum sceptrum. African Journal of Biochemistry Research, 5, 277-281.

[19] Romero, R., Chaiworapongsa, T. and Espinoza, J. (2003) Micronutrients and Intrauterine Infection, Premature Birth and the Fetal Inflammatory Response Syndrome. Journal of Nutrition, 133, 1668S-1673S.

[20] Khuwaja, G., Khan, M.M., Ishrat, T., Ahmad, A., Raza, S.S., Ashafaq, M., Javed, H., Khan, M.B., Khan, A., Vaibhav, K., Safhi, M.M. and Islam, F. (2010) Neuroprotective Effects of Curcumin on 6-hydroxydopamine-Induced Parkinsonism in Rats: Behavioral, Neurochemical and Immunohistochemical Studies. Brain Research, 1368, 254-263.

[21] Demicheli, V., Quijano, C., Alvarez, B. and Radi, R. (2007) Inactivation and Nitration of Human Superoxide Dismutase (SOD) by Fluxes of Nitric Oxide and Superoxide. Free Radical Biology and Medicine, 42, 1359-1368. http://dx.doi.org/10.1016/j.freeradbiomed.2007.01.034

[22] Murray, R.K., Granner, D.K. and Rodwell, V.W. (2006) Harper's Illustrated Biochemistry. 27th Edition, McGraw Hill Education, New York, 400-500. 
Scientific Research Publishing (SCIRP) is one of the largest Open Access journal publishers. It is currently publishing more than 200 open access, online, peer-reviewed journals covering a wide range of academic disciplines. SCIRP serves the worldwide academic communities and contributes to the progress and application of science with its publication.

Other selected journals from SCIRP are listed as below. Submit your manuscript to us via either submit@scirp.org or Online Submission Portal.
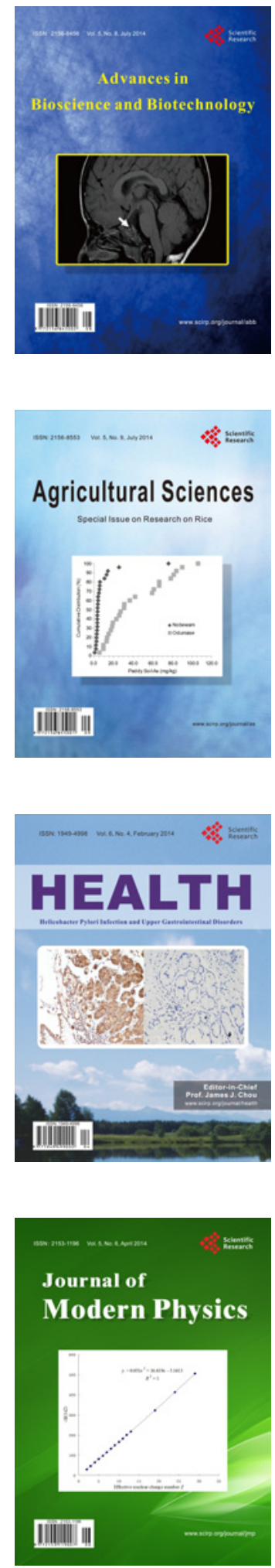
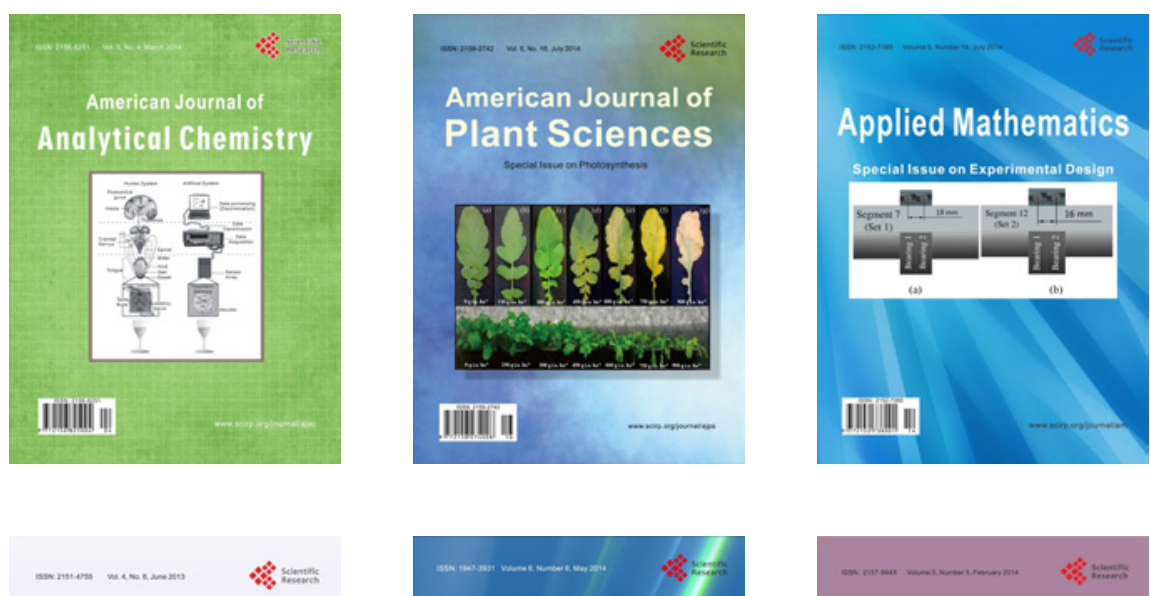

Creative Education
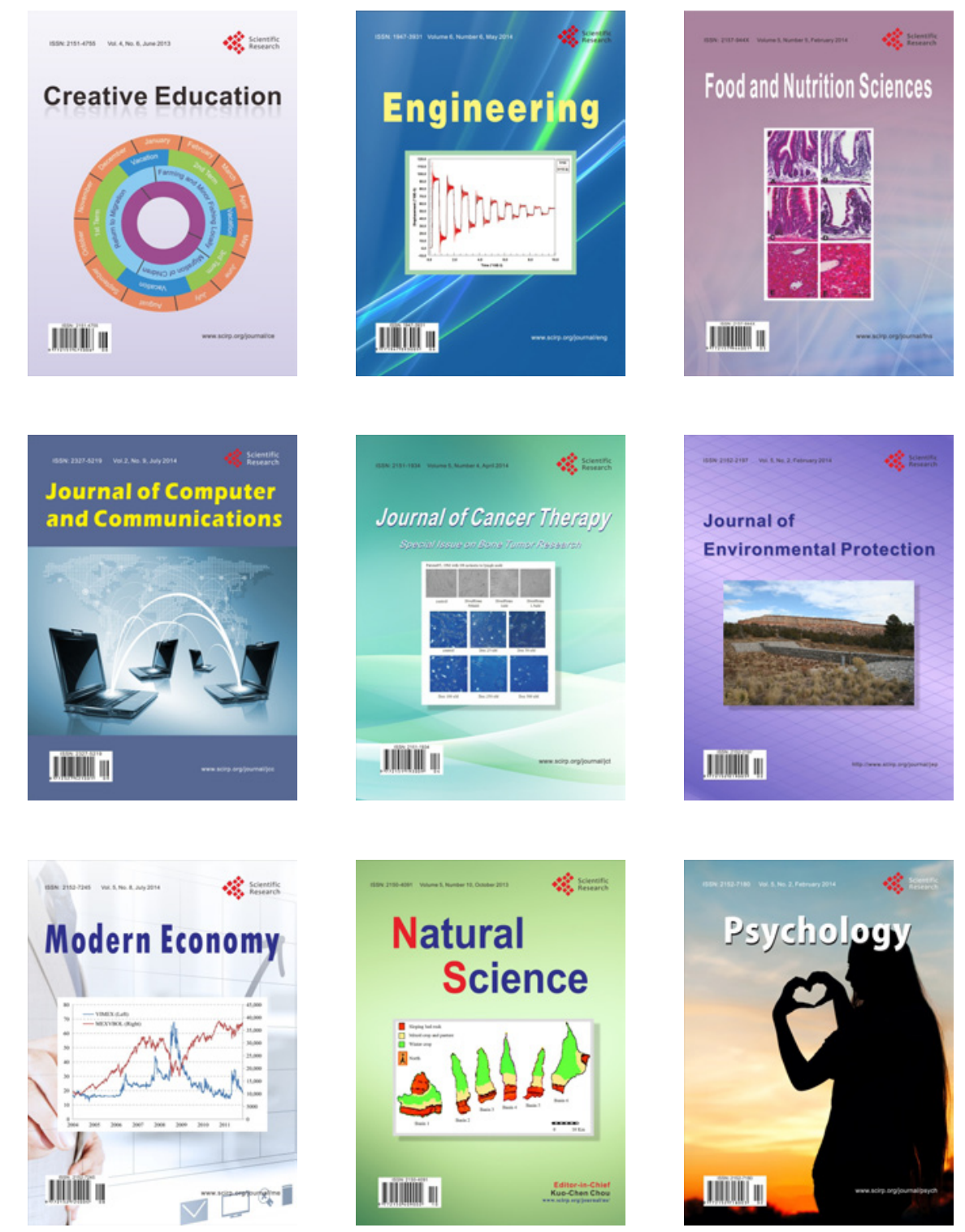